\title{
The Removal of Turbidity and TSS of the Domestic Wastewater by Coagulation-Flocculation Process Involving Oyster Mushroom as Biocoagulant
}

\author{
Astrid Pardede ${ }^{1, *}$, Mochamad Arief Budihardjo ${ }^{1}$, and Purwono ${ }^{1}$ \\ ${ }^{1}$ Department of Environmental Engineering, Faculty of Engineering, Diponegoro University, Semarang - Indonesia
}

\begin{abstract}
Oyster mushroom (Pleurotus ostreatus) can be utilized as biocoagulant since it has chitin cell wall. Chitin has characteristics of bioactivity, biodegradability, absorption and could bind the metal ions. In this study, Oyster Mushroom is micronized and mixed with wastewater to treat turbidity and Total Suspended Solid (TSS) using coagulation-flocculation process employed jartest method. Various doses of Oyster mushroom, $600 \mathrm{mg} / \mathrm{l}, 1000 \mathrm{mg} / \mathrm{l}$, and $2000 \mathrm{mg} / \mathrm{l}$ were tested in several rapid mixing rates which were $100 \mathrm{rpm}, 125 \mathrm{rpm}$, and $150 \mathrm{rpm}$ for 3 minutes followed by 12 minutes of slow mixing at $45 \mathrm{rpm}$. The mixture then was settled for 60 minutes with $\mathrm{pH}$ level maintained at 6-8. The result showed that the Oyster mushroom biocoagulant was able to remove $84 \%$ of turbidity and $90 \%$ of TSS. These reductions were achieved with biocoagulant dose of $600 \mathrm{mg} / \mathrm{L}$ at $150 \mathrm{rpm}$ mixing rate.
\end{abstract}

\section{Introduction}

Coagulation flocculation as a step in water treatment processes is applied for removal of turbidity in raw water that comes from suspended particles and colloidal material [1]. Amongst the available methods of water treatment, coagulation and flocculation (CF) is a low cost, simple, reliable, and low energy consuming process that is commonly practiced. This is because it requires no exclusive or complex machineries; also no energy consumption is required for the operation, once an effective coagulant is obtained. It is an established process that effectively removes soluble, colloidal, and suspended particles through induced aggregation of both micro and macro particulates into larger-sized ones followed by sedimentation. The Coagulation Flocculation operation is not limited to the Aqua removal of particulates alone but also applicable in the removal of other types of pollutants e.g., color, organic compounds, micro-pollutants, and oils and fat [2].

Materials that are used in this stage of water treatment can be inorganic coagulants, synthetic organic polymers or coagulants from natural sources [1]. Some of the most commonly used coagulants are aluminum salts, but they have serious disadvantages, such as, production of harmful sludge and indications that their residues in treated water can be harmful for out health $[3,4,5]$ In spite of its undoubtful effusiveness in turbidity removal, aluminum increases concerns towards ecotoxicological impact when introduced into the environment as post-treatment sludge having large volumes [1]. They are still lacking in terms of green chemistry. In the 1960s, detrimental effects of chemical coagulants on human health were published [6] Further, many researchers have related Alzheimer's disease to the residual aluminum ions in the treated waters [7]. For the application of synthetic organic polymers, concerns about the presence of residual monomers which are neurotoxicity and carcinogenic have impeded its use in water treatment process [8]. One possible solution to these problems may be natural coagulants which are preferable as an alternative excellent method for removing turbidity from water. These coagulants must be safe for health and biodegradable.

In recent years, numerous studies on a variety of plant materials which can be used as source of natural coagulants have been reported. Natural coagulants are widely investigated because of their efficiency, abundant source, low price and biodegradability [5,8,9]. Many materials of plant origin were studied as a source of natural coagulants $[10,11,12]$. The potential of $C$. obtusifolia seed gum, as a natural coagulant, in the treatment of raw and undiluted pulp and paper mill effluent (PPME) was investigated [13] Ocimum basilicum as a natural coagulant for textile wastewater [14] active coagulant agent from Jatropha Curcas seeds for using in turbidity removal [15].

This research has used oyster mushroom as a natural coagulant to reduce turbidity and TSS in canteen's domestic wastewater. Oyster mushroom has chitin as its cell wall $[16,17]$. In recent years, chitin has been applied as flocculants in water and other liquid treatment $[18,19]$ The chitin, polysaccharide composed of $\beta-(1-4)-\mathrm{N}-$ acetyl-D-glucosamine units $(>50 \%)$ and glucosamine units, is a linear semi-crystalline biopolymer which displays $\alpha, \beta$, and $\gamma$ polymorphic forms. This biopolymer is regarded as biocompatible and biodegradable, among many other qualities [20]. 
This research varied the biocoagulant dose to $600 \mathrm{mg}$ / 1, $1000 \mathrm{mg} / 1$ and $2000 \mathrm{mg} / 1$ to obtain the optimum dose. The given rapid mixing velocity was $150 \mathrm{rpm}$ for 3 minutes followed by slow mixing at $45 \mathrm{rpm}$ for 12 minutes and then precipitated for 1 hour.

\section{Methods}

\subsection{Biocoagulant}

- $1 / 4 \mathrm{~kg}$ of oyster mushrooms were blended with 500 $\mathrm{ml}$ of water

- Then the obtained result was squeezed with water until the solids are separated from the liquid

- The solids were ready to serve as biocoagulant

\subsection{Jartest Implementation}

- The biocoagulant according to the existing variations of $600 \mathrm{mg} / 1,1000 \mathrm{mg} / 1$ and $2000 \mathrm{mg}$ / 1 was inserted into the 1-liter glass beaker.

- Then, the canteen's domestic wastewater was mixed up to the volume of 1 liter.

- Do the rapid mixing at $150 \mathrm{rpm}$ for 3 minutes

- Then, slow mixing with $45 \mathrm{rpm}$ of speed for 12 minutes

- Then, the jartest result was precipitated for 1 hour.

\subsection{Turbidity Test (SNI 06-6989.25-2005)}

- Put the $2 / 3$ of sample volume of wastewater into the cuvette, cover and shake.

- Dispose the sample of wastewater and repeat twice

- Clean the cuvette with a tissue

- Press "ON / OFF" button to turn on the tool

- Enter the cuvette in the tool

- Press "READ"

- Read the sample's turbidity

\subsection{TSS Test (SNI 06-6989.25-2005)}

- Heat a clean cup at $105^{\circ} \mathrm{C}$ for 1 hour, then put into desiccators for 15 minutes.

- Weighing the mass of the cup that has been cooled to constant. Record the weight gained (A)

- Heat an ash-free filter paper that has been dampened with aquades at $105^{\circ} \mathrm{C}$ for 1 hour, then put into the desiccators for 15 minutes.

- Weigh the mass of filter paper that has been cooled to constant. Record the weight gained (B)

- Fold the filter paper that previously has been weighed, according to the shape of the used cone. Put the cone with the folded paper on Erlenmeyer.

- Shake the sample up to $100 \mathrm{ml}$ to become homogen.
- Filter the sample using the cone with the filter paper.

- Heat the used filter paper at $105^{\circ} \mathrm{C}$ for 1 hour, then cool it in desiccators for 15 minutes.

- Weigh the filter paper that has been cooled to constant and record the weight gained (C)

- Counting the TSS value with the formula:

$$
T S S(m g / l)=\frac{1000}{100} x\{C-(A+B)\} \times 1000
$$

\section{Results and Discussion}

\subsection{Initial Characteristics of Wastewater}

Table 3.1 Initial Characteristics of Canteen's Domestic Wastewater

\begin{tabular}{|c|c|c|c|c|}
\hline No & $\begin{array}{c}\text { Contamin } \\
\text { ants }\end{array}$ & Result & $\begin{array}{c}\text { Regulation } \\
\text { of } \\
\text { Environme } \\
\text { nt } \\
\text { Minister } \\
\text { No. } \\
\mathbf{6 8 / 2 0 1 6}\end{array}$ & $\begin{array}{c}\text { Informati } \\
\text { on }\end{array}$ \\
\hline 1. & Turbidity & $267 \mathrm{NTU}$ & - & - \\
\hline 2. & TSS & $591 \mathrm{mg} / 1$ & 30 & $\begin{array}{c}\text { Do not } \\
\text { comply }\end{array}$ \\
\hline 3. & pH & 7,41 & $6-9$ & Comply \\
\hline
\end{tabular}

It can be seen in the table that the TSS parameter does not meet the quality standard required by Regulation of the Minister of Environment and Forestry no. 68 of 2016 on the Quality Standards of Domestic Wastewater. Characteristics of canteen's wastewater are influenced by several factors such as the types of food served every day, hours of activity, and the number of buyers who visit. Pollutants that exceed the quality standard can pollute the environment if it is discharged directly into the water body. Therefore a further treatment is required for the effluent before being discharged into the channel.

\subsection{Turbidity Test Results}

The results of turbidity content test in canteen's wastewater after the coagulation flocculation processing by utilizing oyster mushroom biocoagulant are presented in the following table:

Table 3.2 Turbidity Test Results after Processing

\begin{tabular}{|c|c|c|c|c|}
\hline \multirow{2}{*}{ No } & Dose & $\begin{array}{c}\text { Initial } \\
\text { Value }\end{array}$ & $\begin{array}{c}\text { Final } \\
\text { Value }\end{array}$ & Efficiency \\
\cline { 2 - 5 } & $\mathbf{m g}$ & $\mathbf{m g} / \mathbf{l}$ & $\mathbf{m g} / \mathbf{l}$ & $\mathbf{\%}$ \\
\hline 1. & 600 & 267 & 42,44 & 84,1 \\
\hline 2. & 1000 & 267 & 43,2 & 83,82 \\
\hline 3. & 2000 & 267 & 49,2 & 81,57 \\
\hline
\end{tabular}

The chart of turbidity value after coagulation flocculation processing based on oyster mushroom variation is presented in the following graphic image: 
Table 3.4 TSS Test Results after Processing

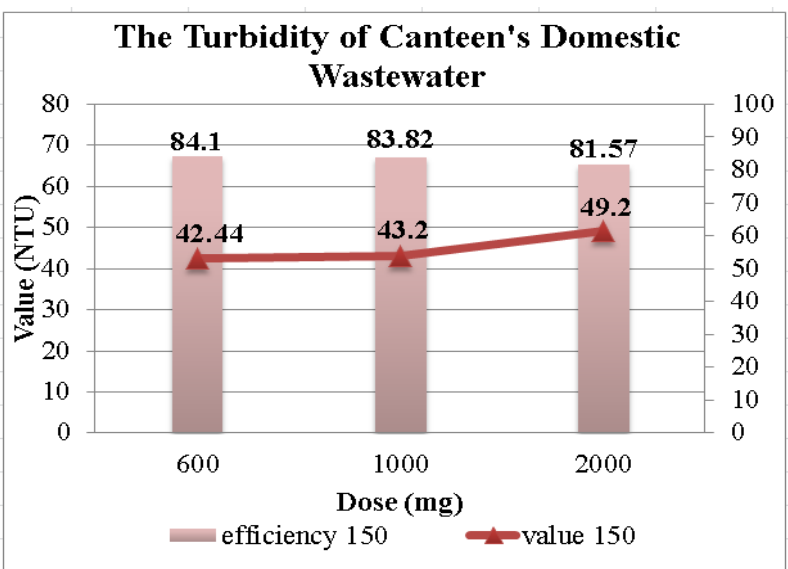

Fig. 1. The Chart of Turbidity Test Result from Canteen's Domestic Wastewater

Table 3.3 Wastewater $\mathrm{pH}$ after processing

\begin{tabular}{|c|c|c|c|}
\hline \multirow{2}{*}{ No } & Dose & $\begin{array}{l}\text { Initial } \\
\text { Value }\end{array}$ & Final Value \\
\cline { 2 - 2 } & $\mathbf{m g} / \mathbf{l}$ & & - \\
\hline 1 & 600 & \multirow{2}{*}{7,41} & 6.19 \\
\hline 2 & 1000 & 6.21 \\
\hline 3 & 2000 & & 6.31 \\
& & & \\
\hline
\end{tabular}

The optimum dose of biocoagulant in the canteen's wastewater was $600 \mathrm{mg} / \mathrm{l}$ that could lower the concentration of turbidity to 42.44 NTU from the initial condition of 267 NTU with $84.1 \%$ efficiency. This phenomenon could be explained by the high content of amine groups in chitin that provide cationic charge at acidic $\mathrm{pH}$ and can destabilize colloidal suspension to promote the growth of large rapid-settling flocs that can then flocculate. As chitin is a long-chain polymer with positive charges at natural water $\mathrm{pH}$, it can effectively flocculate natural particulate and colloidal materials which are negatively charged through mechanism of adsorption, charge neutralization, interparticle bridging as well as hydrophobic flocculation. Chitin gave the highest total solids and total suspended solids reduction at both laboratory and industrial scale [21] Chitin has been widely used as effective coagulant-flocculant for a broad range of suspended solids in various food and fish processing industries and suspension containing mineral colloids in water $[13,21]$ This technique results in the destabilization of colloidal particles and subsequently, the increment in particle size for the ease of sedimentation [22].

\subsection{TSS Test Results}

The results of TSS content test in canteen's wastewater after the coagulation flocculation processing by utilizing oyster mushroom biocoagulant are presented in the following table:

\begin{tabular}{|c|c|c|c|c|}
\hline \multirow{2}{*}{ No } & Dose & $\begin{array}{c}\text { Initial } \\
\text { Value }\end{array}$ & $\begin{array}{c}\text { Final } \\
\text { Value }\end{array}$ & Efficiency \\
\cline { 2 - 4 } & $\mathbf{m g}$ & $\mathbf{m g} / \mathbf{l}$ & $\mathbf{m g} / \mathbf{l}$ & $\mathbf{\%}$ \\
\hline 1. & 600 & \multirow{3}{*}{591} & 55 & 90,69 \\
\hline 2. & 1000 & 89,5 & 84,86 \\
\hline 3. & 2000 & & 113 & 80,87 \\
\cline { 5 - 5 } & & \multicolumn{2}{|c}{} \\
\hline
\end{tabular}

The TSS value chart after coagulation flocculation processing based on oyster mushroom variation is presented in the following chart figure:

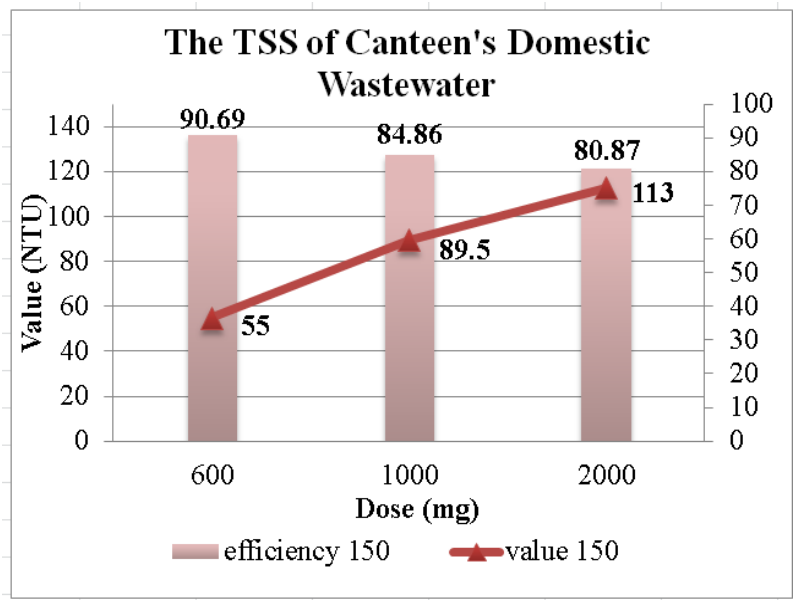

Fig. 2. The Chart of TSS Test Result from Canteen's Domestic Wastewater

Table 3.5 Wastewater $\mathrm{pH}$ after processing

\begin{tabular}{|c|c|c|c|}
\hline \multirow{2}{*}{ No } & Dose & $\begin{array}{c}\text { Initial } \\
\text { Value }\end{array}$ & Final Value \\
\cline { 2 - 2 } & $\mathrm{mg} / \mathrm{l}$ & & - \\
\hline 1 & 600 & \multirow{2}{*}{7,41} & 6.19 \\
\hline 2 & 1000 & 6.21 \\
\hline 3 & 2000 & & 6.31 \\
\hline
\end{tabular}

The optimum dose of biocoagulant in the canteen's wastewater was $600 \mathrm{mg} / \mathrm{l}$ that could lower the concentration of TSS to 55 NTU from the initial condition of 591 NTU with $90.69 \%$ efficiency. The reactivity of chitin during flocculation of suspended particles results from several mechanisms including electrostatic attraction, sorption and bridging. The contribution of each mechanism depends on the $\mathrm{pH}$ of the suspension. This phenomenon could be explained by the high content of amine groups in chitin that provide cationic charge at acidic $\mathrm{pH}$ and can destabilize colloidal suspension to promote the growth of large rapid-settling flocs that can then flocculate. As chitin is a long-chain polymer with positive charges at natural water $\mathrm{pH}$, it can effectively flocculate natural particulate and colloidal materials which are negatively charged through mechanism of adsorption, charge neutralization, interparticle bridging as well as hydrophobic flocculation. Chitin gave the highest total solids and total suspended solids reduction at both laboratory and industrial scale [21]. Chitin has been widely used 
as effective coagulant-flocculants for a broad range of suspended solids in various food and fish processing industries and suspension containing mineral colloids in water $[13,21]$ This technique results in the destabilization of colloidal particles and subsequently, the increment in particle size for the ease of sedimentation [22].

\section{Conclusion}

This research aims to see the ability of oyster mushrooms as biokoagulan to reduce levels of turbidity contaminants and TSS in domestic canteen's domestic wastewater. The optimum dose of oyster mushroom biocoagulant is $600 \mathrm{mg} / \mathrm{l}$ with an efficiency of $84.1 \%$ and turbidity decrease of $90.69 \%$.

\section{References}

1. M. Antov, M. Sciban, N. Petrovic. Bioresource Technology 101, 2167-2172 (2010).

2. N.A. Oladoja. v Journal Of Water Process Engineering 6, 174-192 (2015).

3. M.L. Jodi, U.A. Birnin-Yauri, Y. Yahaya, M.A. Sokoto. Global Adv. Res. J. Chem. Mater. Sci. 1 (4), 71-75 (2012).

4. S.C. Bondy. Neurotoxicology 31, 575-581 (2010).

5. H. Betatache, A. Aouabed, N. Drouiche, H. Lounici. Ecol. Eng. 70, 465-469 (2014).

6. G.S. Simate, S.E. Simate, S. Ndlovu, M. Heydenrych, L.F. Walubita. Environ. Int. 39 (1), 38-49 (2012).

7. H. Aylin Devrimci, A. Mete Yuksel, F. Dilek Sanin, Desalination 299, 16-21 (2012)

8. M. Šćiban, M. Klašnja, M. Antov, B. Škrbić, Bioresour. Technol. 100, 6639-6643 (2009).
9. M. Antov, M. 'S'ciban, J. Prodanovi'c. Ecol. Eng. 49, 48-52 (2012).

10. Ghebremichael, K., Abaliwano, J., Amy, G., J. Water Supply: Res.Technol.- AQUA 58, 267-276, (2009)

11. Teh, C.Y., Wu, T.Y., Juan, J.C., Ecol. Eng. 71, 509519, (2014)

12. Fedala, N., Lounici, H., Drouiche, N., Mameri, N., Drouiche, M., Ecol.Eng. 77, 33-36, (2015)

13 W. Subramonian, T.Y. Wu, S.P. Chai, Ind. CropsProd. 61, 317-324, (2014)

14. S. Shamsnejati, N. Chaibakhsh, A.R. Pendashteh, S. Hayeripour, Ind. Crops Prod. 69, 40-47, (2015)

15. Z. Abidin, N. Shamsudin, N. Madehi, S. Sobri. Optimisation of a method to extract the active coagulant agent from Jatropha Curcas seeds for use in turbidity removal

16. RA. Muzzarelli, J. Boudrant, D. Meyer, N. Manno, M. DeMarchis, MG. Paoletti, Carbohydrate Polymers 87: 995e1012, (2012)

17. P. Maftoun, H. Johari, M. Soltani, R. Malik, N. Z. Othman, and H. A. El Enshasy, International Journal of Biotechnology for Wellness Industries, 4, 67-83, (2015).

18. M.C. Menkiti, O.D Onukwuli. AIChE J. 57, (2011)

19. F. Gassara, C. Antzak, C.M. Ajila, S.J. Sarma, S.K. Brar, M. Verma. Journal of Food Engineering 166 (2015) 80-85

20. P. Kandra, M.M. Challa, H. Kalangi Padma Jyothi, Applied Microbiology \& Biotechnology, 93(1), 1729. (2012).

21. F. Gassara, C. Antzak, C.M. Ajila, S.J. Sarma, S.K. Brar, M. Verma. 2015. Journal of Food Engineering 166, 80-85, (2015)

22. S.Y. Choy, K.M.N. Prasad, T.Y. Wu, M. E. Raghunandan, R. N. Ramanan. Journalo of environmental Sciences 26 2178-2189, (2014) 